\title{
Downregulation of miR-342-3p/miR-342-5p in type 1 diabetes mellitus and vascular health; Case controlled study in peripheral blood mononuclear cells and plasma, CD45dimCD34+CD133+ cells, inflammatory markers, CXCR1/2 and PANEX2 mRNA combined with Ingenuity Pathway Analysis
}

\section{Sabina L Ray}

Translational and Clinical Research Institute

David J Coulson

Translational and Clinical Research Insitute, Newcastle University

Megan LY Yeoh

TRanslational and Clinical Research Institute, Newcastle University

Sherin Bakhashab

TRanslational and Clinical Research Institute, Newcastle University

\section{Alice Tamara}

Translational and Clinical Research Institute, Newcastle University

Jevi S Latief

Translational and Clinical Reasearch Insitute, Newcastle University

Jolanta U Weaver ( $\square$ Jolanta.Weaver@newcastle.ac.uk )

Newcastle University https://orcid.org/0000-0002-3710-2452

Original investigation

Keywords: CXCR1/CXCR2, PANEX2, TNF-a, inflammation, miR-342-3p/-5p, therapeutic targets, TIMP -1, T1DM, CVD

Posted Date: July 10th, 2020

DOI: https://doi.org/10.21203/rs.3.rs-31267/v2

License: (c) (1) This work is licensed under a Creative Commons Attribution 4.0 International License. Read Full License 
The authors have withdrawn this preprint from Research Square 